\title{
EFFECT OF SOME SUPPORTING TYPE, IBA CONCENTRATION AND THEIR INTERACTION ON ROOTING OF In vitro REGENERATED MICRO-SHOOTS OF Polygala myrtifolia $\mathbf{L}$.
}

(Received: 27.4.2010)

\author{
By \\ A. M.Z. Sarhan , E. I. El-Maadawy ,F. M. Saadawy * \\ and T. M. Noor El-Deen*

\begin{abstract}
Ornamental Horticulture Department, Faculty of Agriculture, Cairo University, Giza, Egypt. Agricultural Research Center, Giza, Egypt.
\end{abstract} \\ * Ornamental Plants \& Garden Landscape Research Department, Horticulture Research Institute,
}

\begin{abstract}
A laboratory experiment was carried out at the Tissue Culture Laboratory, Horticulture Research Institute, Agricultural Research Center, during 2008/2009 to induce rooting on the in vitro regenerated micro-shoots of Polygala myrtifolia L. on MS medium. These shoots were supported in the culture using four gelling agents (agar at $7.0 \mathrm{~g} / \mathrm{l}$, gelrite at $2.0 \mathrm{~g} / 1$ and agar+gelrite (at $3.5+1.0 \mathrm{~g} / \mathrm{l}$, respectively), in addition to a filter paper bridge on a liquid MS medium. The micro-shoots were presoaked in different IBA concentrations $(0.0,0.5,1.0$ and $1.5 \mathrm{ppm})$ before inoculation on a growth regulator-free 3/4 MS medium.

Results indicate that rooting \% and total chlorophyll content increased significantly in agar + gelrite solidified medium, while gelrite significantly increased number of roots/plantlet. IBA at 1.0 ppm significantly increased rooting $\%$, the number of roots/plantlet, root length, total chlorophyll, indoles and total soluble sugars $\%$. The combined effect of the supporting type and IBA concentration exerted a significant effect. Rooting \% increased to the significantly highest record when using agar + gelrite in a medium free of IBA.

Therefore, from an economical point of view, it can be recommended in the rooting stage to use agar + gelrite (at 3.5+1.0 g/l MS medium, respectively) without presoaking in IBA solutions to obtain the highest rooting $\%$.
\end{abstract}

Key words: agar, filter paper bridge, gelrite, IBA, in vitro, Polygala myrtifolia, rooting.

\section{INTRODUCTION}

Myrtle leaf (Polygala myrtifolia L., Fam. Polygalaceae), native to South Africa is one of many species of trees and shrubs used in the garden landscape. It is a decorative evergreen shrub; grows to 2 meters in height with crowded, slender branches forming a willowy, ovalshaped bush. The pale purple flowers are peashaped, produced in profusion at the tips of the slender branchlets with long flowering period, extending from early spring through the winter when many other plants are not flowering, (Oakman, 1995 and Iapichino, 2004). On the other hand, using standard methods of propagation, $P$. myrtifolia cuttings are slow and difficult to root (Iapichino and Airo, 2002). Consequently, micropropagation might be more effective for the rapid and mass propagation of P. myrtifolia.
Many factors affect rooting in vitro as gelling agents, auxin type and concentration, media strength, other chemical additions and incubation conditions. Concerning the gelling agents, Ebrahim and Ibrahim (2000) found that agar and gelrite applied (at 5 and $1.5 \mathrm{~g} / \mathrm{l}$, respectively) induced rooting of Maranta leuconeura. They also stated that adding agar plus gelrite at the rate of $5+0.5 \mathrm{~g} / \mathrm{l}$, respectively, extremely enhanced rooting. Orlikowska et al. (2000) found that diluting MS medium by half when combined with $2 \mathrm{mg} /$ litre gelrite instead of 7 g/litre agar stimulated root growth of Codiaeum variegatum cv. Excellent shoots produced in vitro. Cao and Earle (2003) showed that the use of a 1:1 mixture of Agar gel and Gelrite in the rooting medium increased the number of healthy roots per rooted plantlet of transgenic broccoli explants. AbdShukor et al. 
(2008) cleared that MS medium supplemented only with $0.24 \%$ gelrite was the most effective treatment producing the longest root length of Azadirachta excelsa. In the same manner the positive effect of a liquid medium supported with filter paper was observed by many research workers. Zeng et al. (2009) reported that eighty percent of the shoots rooted, and an average of 2.0 roots per shoot was achieved when a basal portion of Citrus reticulata Blanco regenerated shoots was dipped into $1000 \mathrm{mg} / \mathrm{l} \mathrm{IBA}$ solution for $15 \mathrm{~min}$ before placement on a filter-paper bridge. Bhattacharya and Bhattacharyya (2010) stated that emergence and elongation of Jasminum officinale L, roots from shoot base was facilitated by placing on the notch of a filter paper bridge.

Some authors noticed that the type and concentration of the used auxin. As well as the method by which auxins are used have a conspicuous effect on the obtained result. Radice (2000) reported that root induction of Codiaeum variegatum Blume cv Norma (croton) was observed on a basal medium plus $1 \mathrm{mg} / \mathrm{l}$ IBA. Romano et al. (2002) achieved rooting of Ceratonia siliqua in vitro on a growth regulator free medium after basal dipping of shoots in IBA at $4.9 \mathrm{mM}(1 \mathrm{ppm})$ instead of inclusion of auxins in MS medium. In the same regard Iqbal et al. (2003) showed that roots of proliferated shoots of 'Hybrid Tea' rose cultivars Rosy Cheek and Whisk Mac were only regenerated in MS medium supplemented with $0.5 \mathrm{mg}$ IBA/liter. Romano and Martins-Loucao (2003) reported that the rooting percentage of Quercus suber was improved to $95 \%$ by basal immersion of shoots in $0.5 \mathrm{~g} /$ litre IBA for 2 minutes. Behera and Thirunavoukkarasu (2006) stated that rooting of in vitro Desmodium gangeticum shootlets was better in $1.0 \mathrm{mg} / \mathrm{l} \mathrm{IBA}$-supplemented medium than IAA. Burasheed et al. (2006) found that the highest rooting percentage was obtained with half-strength MS medium supplemented with IBA at $3.0 \mathrm{mg} /$ litre for date palm cv. Barhee, while for cv. Khalas, 3.0 or $5.0 \mathrm{mg} / \mathrm{litre}$ produced the highest rooting percentage and root number/shoot. The longest roots were obtained with IBA at $1.0 \mathrm{mg} / \mathrm{litre}$. Hung et al. (2006) stated that root formation of Wasabia japonica (Miq.) was greatest with IBA when compared with IAA and NAA. Mehta et al. (2007) mentioned that well developed root system of carnation (Dianthus caryophyllus) was obtained in vitro on a liquid MS medium supplemented with $2.0 \mathrm{mg} / \mathrm{l} \mathrm{IBA}$ and $0.2 \%$ activated charcoal.
Nisha et al. (2009) reported that root induction on shoots of Begonia malabarica in vitro was achieved on a full strength MS with IAA/IBA at different concentrations $(0.0-2.88 \mathrm{mg} / \mathrm{l})$. The regenerated shoots were rooted on MS with 1.2 $\mathrm{mg} / \mathrm{l}$ IBA. Waseem et al. (2009) found that rooting response of chrysanthemum was obtained in a half strength MS medium supplemented with $0.2 \mathrm{mg} / \mathrm{l}$ indole butyric acid (IBA).

\section{MATERIALS AND METHODS}

This experiment was carried out at the Tissue Culture Laboratory, Horticulture Research Institute, Agricultural Research Center, during 2008/2009 season to induce root formation of Polygala myrtifolia L. in vitro regenerated micro-shoots by using different support type, IBA concentrations applied as presoaking and their combinations.

\subsection{Explant preparation}

Actively growing terminal shoots, $10 \mathrm{~cm}$ in length were obtained from 2-year-old Polygala myrtifolia plants grown in pots in the experimental nursery of Ornamental Plant Researches and Landscape Department,A.R.C., Giza. The leaves were completely removed, the bare shoots were rinsed under running tap water for about 20 minutes, immersed for 15 minutes in $20 \%$ Clorox solution (4-5\% sodium hypochlorite) for disinfection and finally rinsed 3 times with sterilized distilled water. Under aseptic conditions, these shoots were cut into one node segments $(1.5 \mathrm{~cm}$ length) and placed vertically on MS basal medium supplied with 30 $\mathrm{g} / 1$ sucrose, $7 \mathrm{~g} / 1$ agar and $0.4 \mathrm{mg} / \mathrm{l} \mathrm{BA}$. Four weeks later, the new in vitro produced shoots were transferred to fresh media (with the same previous composition) for multiplication in order to obtain multiple regenerated micro-shoots. After a similar interval, the in vitro regenerated micro-shoots $(1.5 \mathrm{~cm}$ long with intact apices and 3-4 leaves) were moved forward to the rooting stage where they were subjected to different rooting treatments.

\subsubsection{Cultural medium and incubation conditions}

Murashige and Skoog (1962) nutrient medium (MS) was used at 3/4 strength. This medium contained, in addition to the prescribed salts and vitamins, with $30 \mathrm{~g} / \mathrm{l}$ sucrose and was solidified with different gelling agents according to the experimental scheme. It was then adjusted to $\mathrm{pH} 5.8$, poured in glass jars $(11.5 \mathrm{~cm}$ height $\times$ $6.5 \mathrm{~cm}$ diameter with their polypropylene caps) 
and autoclaved at $121{ }^{\circ} \mathrm{C}$ for 20 minutes under $1.05 \mathrm{~kg} / \mathrm{cm}^{2}$ pressure, left to cool and stored at $25 \pm 2^{\circ} \mathrm{C}$ for one week before being used. After shoots were inoculated in the medium, the jars were incubated in growth chambers at $25^{\circ} \mathrm{C}$ under 16 hrs. photoperiod using Philips coolwhite fluorescent tubes at light intensity of 3000 Lux (about $36.3 \mu \mathrm{mol} / \mathrm{m}^{2} / \mathrm{s}$ ) till the data were collected about 8 weeks later.

\subsection{Experimental treatments}

\subsubsection{Support type}

In order to support shoots in the culture medium, this medium has to be solidified by a gelling agent. However, liquid medium can be used, provided a certain kind of support is available. In this regard, a filter paper can be used to avoid submersion of the explant. In the current study, shoots were inoculated on three different solid media, in addition to a liquid one. The first two media were solidified by either agar at $7.0 \mathrm{~g}$ or gelrite at $2.0 \mathrm{~g} / \mathrm{l} \mathrm{MS}$ medium. Gelling was achieved in the third medium by a combination of agar at $3.5 \mathrm{~g}$ and gelrite at $1.0 \mathrm{~g} / \mathrm{l}$ MS medium. In the fourth treatment where a liquid MS medium was used, the explant was supported with filter paper bridge (made of Whatman No. 9).

\subsubsection{IBA concentration}

In vitro microshoots were soaked before being cultured in the medium in either one of four IBA concentrations $(0.0,0.50,1.00$ and $1.50 \mathrm{ppm}$ ) for 2 minutes according to Romano and Martins-Loucao (2003).

At the end of this experiment, the following data were recorded: survival percentage, rooting percentage, number of roots/plantlet, root length (cm), total chlorophyll (mg/100 g F.W.) according to Moran (1982), total indoles (mg/100 g F.W.) as described by A.O.A.C. (1990) and the percentage of total soluble sugars according to Dubois et al. (1956). Data were recorded after 8 weeks.

\subsubsection{Statistical analysis}

The design used was a completely randomized design in a factorial experiment as described by Snedecor and Cochran (1980) at $5 \%$ probability level. The supporting agent represents the first factor (four levels), while IBA concentrations represent the second one (four levels). Each one of the 16 treatments consisted of 3 replicates, with 6 jars in every replicate. Data obtained were statistically analyzed using MSTAT Computer Program (1985) and means were compared by Duncan's
Multiple Range Test (1955) to verify differences among the means of various treatments.

\section{RESULTS}

Effect of gelling agents, IBA concentration and their interaction on

\subsection{Survival percentage}

It can be observed from Table (1) that the supporting type significantly influenced survival percentage of $P$. myrtifolia in vitro regenerated micro-shoots during rooting stage. Gelrite and agar+gelrite significantly induced the highest values in this respect (74.78 and $79.22 \%$, respectively), compared to agar or the filter paper bridge support. It can be also observed that the effect of agar+gelrite was higher than that of gelrite. However, the difference was not significant.

Presoaking the in vitro produced Polygala shoots in IBA solutions decreased the survival\% significantly. This decrement was related significantly and inversely to IBA level. The more the IBA level increased, the less the survival $\%$ was. The highest significant value in this regard was obtained when the shoots were not presoaked $(87.31 \%)$.

The interaction between supporting type and IBA concentrations was found to be significant. Data in Table (1) show that inoculating on agar or agar+gelrite, without presoaking in IBA solution, resulted in the survival of all inoculated shoots. This was followed, without significant difference by presoaking in IBA at $0.5 \mathrm{ppm}$ before inoculating on agar+gelrite $(90.28 \%)$.

\subsection{Rooting percentage}

Rooting \% increased to the significantly highest record when using agar+gelrite $(54.87 \%)$ as presented in Table (2). On the other hand, agar presented the next value of rooting percentage, while gelrite and filter paper recorded the lowest values.

The effect of using different IBA concentrations on rooting percentage was significant. It can be noticed that the significantly highest rooting percentage (51.60\%) was recorded when shoots were presoaked in IBA at $1.0 \mathrm{ppm}$. Increasing or decreasing IBA concentration over the former level significantly reduced rooting percentage.

With regard to the interaction between supporting type and IBA concentrations on rooting percentage, the significantly highest record $(71.43 \%)$ was achieved by using agar+gelrite without IBA as a presoaking treatment, followed without significant 
Table (1) : Effect of supporting type and IBA concentration on survival\% of Polygala myrtifolia after 8 weeks

\begin{tabular}{|c|c|c|c|c|c|}
\hline \multirow{2}{*}{ IBA conc. (ppm) } & \multicolumn{4}{|c|}{ Supporting type } & \multirow{2}{*}{ Mean } \\
\cline { 2 - 5 } & Agar & Gelrite & Agar+gelrite & Filter paper & \\
\hline 0.0 & $100.00 \mathrm{a}$ & $79.44 \mathrm{bc}$ & $100.00 \mathrm{a}$ & $69.81 \mathrm{c}-\mathrm{f}$ & $87.31 \mathrm{~A}$ \\
\hline 0.5 & $61.51 \mathrm{e}-\mathrm{g}$ & $76.59 \mathrm{~cd}$ & $90.28 \mathrm{ab}$ & $65.08 \mathrm{~d}-\mathrm{g}$ & $73.36 \mathrm{~B}$ \\
\hline 1.0 & $59.05 \mathrm{f}-\mathrm{h}$ & $73.81 \mathrm{c}-\mathrm{e}$ & $71.43 \mathrm{c}-\mathrm{f}$ & $57.94 \mathrm{f}-\mathrm{h}$ & $65.56 \mathrm{C}$ \\
\hline 1.5 & $45.45 \mathrm{~h}$ & $69.26 \mathrm{c}-\mathrm{f}$ & $55.19 \mathrm{gh}$ & $45.83 \mathrm{~h}$ & $53.93 \mathrm{D}$ \\
\hline Mean & $66.50 \mathrm{~B}$ & $74.78 \mathrm{~A}$ & $79.22 \mathrm{~A}$ & $59.67 \mathrm{C}$ & \\
\hline
\end{tabular}

* Means with the same letter are not significantly different at 0.05 level of significance.

Table (2): Effect of supporting type and IBA concentration on rooting\% of Polygala myrtifolia after 8 weeks

\begin{tabular}{|c|c|c|c|c|c|}
\hline \multirow{2}{*}{ IBA conc. (ppm) } & \multicolumn{4}{|c|}{ Supporting type } & \multirow{2}{*}{ Mean } \\
\cline { 2 - 5 } & Agar & Gelrite & Agar+gelrite & Filter paper & Mea \\
\hline $\mathbf{0 . 0}$ & $25.92 \mathrm{gh}$ & $37.78 \mathrm{e}-\mathrm{h}$ & $71.43 \mathrm{a}$ & $24.44 \mathrm{~h}$ & $39.89 \mathrm{~B}$ \\
\hline $\mathbf{0 . 5}$ & $28.89 \mathrm{gh}$ & $24.52 \mathrm{~h}$ & $50.00 \mathrm{c}-\mathrm{f}$ & $50.95 \mathrm{~b}-\mathrm{f}$ & $38.59 \mathrm{~B}$ \\
\hline $\mathbf{1 . 0}$ & $66.67 \mathrm{ab}$ & $41.11 \mathrm{~d}-\mathrm{g}$ & $62.50 \mathrm{a}-\mathrm{c}$ & $36.11 \mathrm{e}-\mathrm{h}$ & $51.60 \mathrm{~A}$ \\
\hline $\mathbf{1 . 5}$ & $52.22 \mathrm{~b}-\mathrm{e}$ & $55.12 \mathrm{a}-\mathrm{d}$ & $35.55 \mathrm{f}-\mathrm{h}$ & $23.33 \mathrm{~h}$ & $41.56 \mathrm{~B}$ \\
\hline Mean & $43.42 \mathrm{~B}$ & $39.63 \mathrm{BC}$ & $54.87 \mathrm{~A}$ & $33.71 \mathrm{C}$ & 42.91 \\
\hline
\end{tabular}

* Means with the same letter are not significantly different at 0.05 level of significance.

differences with IBA at $1.0 \mathrm{ppm+agar,} \mathrm{IBA} \mathrm{at}$ $1.0 \mathrm{ppm}+$ agar+gelrite and finally IBA at 1.5 ppm+gelrite. The lowest rooting\% was obtained when the shoots were presoaked in IBA at 1.5 ppm before being supported by a filter paper bridge (23.33\%).

\subsection{Number of roots/plantlet}

Data in Table (3) show that although there was no significant difference between agar, gelrite and agar+gelrite in increasing this trait, these three treatments gave significantly higher values, compared with the result of using filter paper bridge as a support tool. Among the previous mentioned three treatments, gelrite seem to be more effective in increasing this character compared to other treatments.

Presoaking in IBA at 1.0 or $0.5 \mathrm{ppm}$ significantly produced the highest number of roots/plantlet (5.03 and 4.70, respectively), compared to the other treatments. The lowest number of roots/plantlet was found on the untreated plants (3.80).

The interaction between supporting type and IBA concentrations was significant. Agar+IBA (either at 1.0 or $0.5 \mathrm{ppm}$ ) significantly increased the number of roots/plantlet to the significantly highest level, with the first combination (5.89) being higher than the second one (5.44). On the other hand, using filter paper bridge either without IBA or with IBA at $1.5 \mathrm{ppm}$ gave the significantly lowest records (3.42 and 3.44, respectively).

\subsection{Root length}

Results in Table (4) show the effect of supporting type on root length of $P$. myrtifolia plantlets. The significantly longest roots were produced when a filter paper bridge was used to support the shoots on the liquid medium (6.51 $\mathrm{cm})$. Other values produced by other supporting means, i.e. gelrite, agar+gelrite and agar came significantly in the second, third and fourth categories $(4.93,4.55$ and $3.76 \mathrm{~cm})$, respectively, with significant differences in between. Agar resulted in the shortest roots.

The effect of IBA concentrations was found to be significant. IBA at $1.0 \mathrm{ppm}$ significantly recorded the longest root $(5.55 \mathrm{~cm})$. Values of root length at other concentrations came in the second position, with no significant difference in between.

A significant interaction was observed between supporting type and IBA concentrations. The combined treatment of filter paper bridge+ IBA at $1.0 \mathrm{ppm}$ significantly produced the longest roots $(7.78 \mathrm{~cm})$ compared with other treatments, followed in the second rank by the filter paper+ IBA at $0.5(6.67 \mathrm{~cm})$ or with no IBA $(6.56 \mathrm{~cm})$. Roots produced on agar with no IBA were significantly the shortest $(2.44$ $\mathrm{cm})$.

\subsection{Total chlorophylls}

The effect of different supporting types and IBA concentrations on the total chlorophylls was significant (Table 5). Agar+gelrite proved to be superior in enhancing total chlorophyll content in plantlet leaves as it gave the significantly highest record in this concern $(3.51 \mathrm{mg})$. The 
Table (3): Effect of supporting type and IBA concentration on the number of roots/plantlet of Polygala myrtifolia after 8 weeks

\begin{tabular}{|c|l|c|c|c|c|}
\hline \multirow{2}{*}{ IBA conc. (ppm) } & \multicolumn{4}{|c|}{ Supporting type } & \multirow{2}{*}{ Mean } \\
\cline { 2 - 5 } & Agar & Gelrite & Agar+gelrite & Filter paper & \\
\hline $\mathbf{0 . 0}$ & $2.55 \mathrm{f}$ & $4.35 \mathrm{~cd}$ & $4.89 \mathrm{bc}$ & $3.42 \mathrm{e}$ & $3.80 \mathrm{~B}$ \\
\hline $\mathbf{0 . 5}$ & $5.44 \mathrm{ab}$ & $4.64 \mathrm{bc}$ & $4.28 \mathrm{~cd}$ & $4.42 \mathrm{~cd}$ & $4.70 \mathrm{~A}$ \\
\hline $\mathbf{1 . 0}$ & $5.89 \mathrm{a}$ & $4.67 \mathrm{bc}$ & $4.83 \mathrm{bc}$ & $4.72 \mathrm{bc}$ & $5.03 \mathrm{~A}$ \\
\hline $\mathbf{1 . 5}$ & $4.22 \mathrm{c}-\mathrm{e}$ & $4.97 \mathrm{bc}$ & $3.61 \mathrm{de}$ & $3.44 \mathrm{e}$ & $4.06 \mathrm{~B}$ \\
\hline Mean & $4.53 \mathrm{~A}$ & $4.66 \mathrm{~A}$ & $4.40 \mathrm{~A}$ & $4.00 \mathrm{~B}$ & \\
\hline
\end{tabular}

* Means with the same letter are not significantly different at 0.05 level of significance.

Table (4): Effect of supporting type and IBA concentration on root length $(\mathrm{cm})$ of Polygala myrtifolia after 8 weeks

\begin{tabular}{|c|c|c|c|c|c|}
\hline \multirow[t]{2}{*}{ IBA conc. (ppm) } & \multicolumn{4}{|c|}{ Supporting type } & \multirow[t]{2}{*}{ Mean } \\
\hline & Agar & Gelrite & Agar+gelrite & Filter paper & \\
\hline 0.0 & $2.44 \mathrm{f}$ & $5.00 \mathrm{~cd}$ & $4.67 \mathrm{~cd}$ & $6.56 \mathrm{~b}$ & $4.67 \mathrm{~B}$ \\
\hline 0.5 & $3.42 \mathrm{e}$ & $4.79 \mathrm{~cd}$ & $4.39 \mathrm{~d}$ & $6.67 \mathrm{~b}$ & $4.82 \mathrm{~B}$ \\
\hline 1.0 & $4.88 \mathrm{~cd}$ & $5.22 \mathrm{c}$ & $4.32 \mathrm{~d}$ & $7.78 \mathrm{a}$ & $5.55 \mathrm{~A}$ \\
\hline 1.5 & $4.29 \mathrm{~d}$ & $4.71 \mathrm{~cd}$ & $4.81 \mathrm{~cd}$ & $5.03 \mathrm{~cd}$ & $4.71 \mathrm{~B}$ \\
\hline Mean & $3.76 \mathrm{D}$ & $4.93 \mathrm{~B}$ & $4.55 \mathrm{C}$ & $6.51 \mathrm{~A}$ & \\
\hline
\end{tabular}

* Means with the same letter are not significantly different at 0.05 level of significance.

Table (5): Effect of supporting type and IBA concentration on total chlorophyll content (mg/100g F.W.) of Polygala myrtifolia after 8 weeks

\begin{tabular}{|c|c|c|c|c|c|}
\hline \multirow{2}{*}{ IBA conc. $(\mathbf{p p m})$} & \multicolumn{4}{|c|}{ Supporting type } & \multirow{2}{*}{ Mean } \\
\cline { 2 - 5 } & Agar & Gelrite & Agar+gelrite & Filter paper & \\
\hline $\mathbf{0 . 0}$ & $2.78 \mathrm{c}$ & $2.42 \mathrm{c}-\mathrm{e}$ & $2.26 \mathrm{~d}-\mathrm{f}$ & $2.55 \mathrm{~cd}$ & $2.50 \mathrm{C}$ \\
\hline $\mathbf{0 . 5}$ & $3.33 \mathrm{~b}$ & $2.04 \mathrm{ef}$ & $2.34 \mathrm{c}-\mathrm{f}$ & $3.33 \mathrm{~b}$ & $2.76 \mathrm{~B}$ \\
\hline $\mathbf{1 . 0}$ & $2.77 \mathrm{c}$ & $3.54 \mathrm{~b}$ & $4.56 \mathrm{a}$ & $3.39 \mathrm{~b}$ & $3.57 \mathrm{~A}$ \\
\hline $\mathbf{1 . 5}$ & $1.93 \mathrm{f}$ & $4.47 \mathrm{a}$ & $4.87 \mathrm{a}$ & $3.68 \mathrm{~b}$ & $3.74 \mathrm{~A}$ \\
\hline Mean & $2.70 \mathrm{C}$ & $3.12 \mathrm{~B}$ & $3.51 \mathrm{~A}$ & $3.24 \mathrm{~B}$ & \\
\hline
\end{tabular}

* Means with the same letter are not significantly different at 0.05 level of significance.

significantly lowest one belonged to plantlets grown on agar $(2.70 \mathrm{mg})$. Values of other supporting types; i.e., gelrite and filter paper occupied significantly the second position.

Shoots presoaked in IBA at 1.5 or $1.0 \mathrm{ppm}$ prior to culturing on growth regulators-free MS medium had significantly the highest content of total chlorophylls (3.74 and $3.57 \mathrm{mg}$, respectively). The same content of shoots grown on a medium supplemented with IBA at $0.5 \mathrm{ppm}$ occupied the second position, while that of shoots deprived of IBA treatment was significantly the lowest.

The interaction between supporting types and IBA concentrations was significant. Agar+gelrite + IBA at 1.5 or $1.0 \mathrm{ppm}$ in addition to gelrite+IBA at $1.5 \mathrm{ppm}(4.87,4.56$ and 4.47 $\mathrm{mg}$, respectively) resulted in the significantly highest total chlorophyll content compared to the corresponding records of other combined treatments. The significantly lowest total chlorophyll content was found in plantlets supported with agar+IBA at $1.5 \mathrm{ppm}$, gelrite with IBA at $0.5 \mathrm{ppm}$ and agar+gelrite with no or 0.5 IBA treatment.

\subsection{Indole content in plantlets}

The effect of different supporting type on indole content as shown in Table (6) is significant. Agar significantly produced the highest content $(4.59 \mathrm{mg})$, while aga+gelrite scored the significantly lowest record $(2.81 \mathrm{mg})$ in the same regard. The other two treatments resulted in values occupying the second position, significantly.

IBA at 1.0 and $1.5 \mathrm{ppm}$ produced the highest significant indole content, with IBA at $1.5 \mathrm{ppm}$ more effective than IBA at $1.0 \mathrm{ppm}$ (4.22 and $4.00 \mathrm{mg}$, respectively) but the difference was not significant. The untreated control shoots and those treated with IBA at $0.5 \mathrm{ppm}$ achieved lower results in this concern.

The interaction between supporting type and IBA concentrations was significant. Agar plus IBA at $1.5 \mathrm{ppm}$ significantly produced the highest indole content $(7.69 \mathrm{mg})$. The second category value was recorded by gelrite plus IBA 
Table (6): Effect of supporting type and IBA concentration on indole content $(\mathrm{mg} / 100 \mathrm{~g}$

F.W.) of Polygala myrtifolia after 8 weeks

\begin{tabular}{|c|c|c|c|c|c|}
\hline \multirow{2}{*}{ IBA conc. (ppm) } & \multicolumn{4}{|c|}{ Supporting type } & \multirow{2}{*}{ Mean } \\
\cline { 2 - 5 } & Agar & Gelrite & Agar+gelrite & Filter paper & \\
\hline $\mathbf{0 . 0}$ & $2.30 \mathrm{gh}$ & $3.30 \mathrm{de}$ & $2.88 \mathrm{~d}-\mathrm{f}$ & $5.21 \mathrm{c}$ & $3.42 \mathrm{~B}$ \\
\hline $\mathbf{0 . 5}$ & $3.12 \mathrm{~d}-\mathrm{f}$ & $6.50 \mathrm{~b}$ & $2.96 \mathrm{~d}-\mathrm{f}$ & $2.04 \mathrm{~h}$ & $3.66 \mathrm{~B}$ \\
\hline $\mathbf{1 . 0}$ & $5.24 \mathrm{c}$ & $2.75 \mathrm{e}-\mathrm{g}$ & $2.69 \mathrm{fg}$ & $5.32 \mathrm{c}$ & $4.00 \mathrm{~A}$ \\
\hline $\mathbf{1 . 5}$ & $7.69 \mathrm{a}$ & $3.11 \mathrm{~d}-\mathrm{f}$ & $2.72 \mathrm{fg}$ & $3.34 \mathrm{~d}$ & $4.22 \mathrm{~A}$ \\
\hline Mean & $4.59 \mathrm{~A}$ & $3.92 \mathrm{~B}$ & $2.81 \mathrm{C}$ & $3.98 \mathrm{~B}$ & \\
\hline
\end{tabular}

* Means with the same letter are not significantly different at 0.05 level of significance.

Table (7): Effect of supporting type and IBA concentration on total soluble sugars\% of Polygala myrtifolia after 8 weeks

\begin{tabular}{|c|c|c|c|c|c|}
\hline \multirow{2}{*}{ IBA conc. (ppm) } & \multicolumn{4}{|c|}{ Supporting type } & \multirow{2}{*}{ Mean } \\
\cline { 2 - 5 } & Agar & Gelrite & Agar+gelrite & Filter paper & \\
\hline $\mathbf{0 . 0}$ & $2.06 \mathrm{k}$ & $2.86 \mathrm{ij}$ & $2.90 \mathrm{ij}$ & $8.41 \mathrm{c}$ & $4.06 \mathrm{~d}$ \\
\hline $\mathbf{0 . 5}$ & $2.34 \mathrm{jk}$ & $4.38 \mathrm{~g}$ & $6.17 \mathrm{e}$ & $9.20 \mathrm{~b}$ & $5.52 \mathrm{c}$ \\
\hline $\mathbf{1 . 0}$ & $2.98 \mathrm{i}$ & $5.20 \mathrm{f}$ & $6.81 \mathrm{~d}$ & $10.78 \mathrm{a}$ & $6.44 \mathrm{a}$ \\
\hline $\mathbf{1 . 5}$ & $3.96 \mathrm{gh}$ & $3.45 \mathrm{hi}$ & $6.15 \mathrm{e}$ & $10.55 \mathrm{a}$ & $6.03 \mathrm{~b}$ \\
\hline Mean & $2.84 \mathrm{~d}$ & $3.97 \mathrm{c}$ & $5.51 \mathrm{~b}$ & $9.74 \mathrm{a}$ & \\
\hline
\end{tabular}

* Means with the same letter are not significantly different at 0.05 level of significance.

at $0.5 \mathrm{ppm}$. The lowest values were those resulted by filter paper bridge+IBA at $0.5 \mathrm{ppm}$ (2.04 mg).

\subsection{Total soluble sugars}

The total soluble sugars \% increased significantly to the highest level by using the filter paper as a supporting tool in the liquid medium $(9.74 \%)$. On the other hand, shoots grown on agar+gelrite had this parameter in the second position $(5.51 \%)$. The significantly lowest value was induced by culturing on agar medium (2.84\%) (Table ,7).

Presoaking $P$. myrtifolia microshoots in IBA at $1.0 \mathrm{ppm}$ produced the significantly highest percentage of total soluble sugars $(6.44 \%)$, followed by IBA at $1.5 \mathrm{ppm}(6.03 \%)$. The significantly lowest percentage was a result of using no IBA at all.

The combined treatments of filter paper bridge + IBA (at either 1.0 or $1.5 \mathrm{ppm}$ ) produced the significantly highest values (10.78 and $10.55 \%$, respectively) compared with other treatments. The lowest value was obtained when inoculating on agar with no IBA treatment.

\section{DISCUSSION}

All the previously mentioned results are in agreement with those obtained by some authors. Ebrahim and Ibrahim (2000) found that adding agar plus gelrite at the rate of $5+0.5 \mathrm{~g} / \mathrm{l}$, respectively, extremely enhanced rooting. Cao and Earle (2003) on broccoli found that the use of a 1:1 mixture of Agar gel and Gelrite in the rooting medium increased the number of healthy roots/rooted plantlet.

Concerning the effect of IBA concentrations, shoots could be induced to root without auxins or with relatively low concentration, Atta-Alla et al. (2003) stated that rooting of proliferated shoots of Bombax malabaricum was on MS medium containing different IBA concentrations (0.0-3.0 $\mathrm{mg} / \mathrm{l})$, IBA at low concentrations resulted in the highest number of developed roots. Hashem et al. (2005) found that, increasing IBA concentration affected rooting \% of Conocarpus erectus negatively. Hongrat et al. (2005) ascertained that the medium without plant growth regulators produced the highest average number of roots of Cryptocoryne cordata. However, Banilas and Korkas (2007) reported that relatively low concentrations of indole-3-butyric acid (IBA) promoted both the frequency of shoots forming roots and the number of roots per shoot of grapevine (Vitis vinifera) cv. Agiorgitiko genotypes. It may be postulated that the high rooting percentage of micro-shoots cultured in growth regulator-free MS medium may be attributed to the high concentrations of endogenous auxins in these cuttings. If this assumption is true, the application of exogenous auxins may have led to super optimal concentrations in plant tissues, with negative effects on rooting.

In conclusion, from the economical point of view, it is recommended during rooting stage to use agar+gelrite (at 3.5 and $1.0 \mathrm{~g} / \mathrm{l} \mathrm{MS}$ medium, 
respectively) without presoaking IBA solutions in order to obtain the highest percentage of rooting.

\section{REFERENCES}

A. O. A. C. (1990). The Association of Official Agricultural Chemists. $15^{\text {th }}$ Ed. Arlington, Virginia 22201:877-878.

AbdShukor N.A., Jainol J. E., Yusoff A.M., and Abd Kadir M. (2008). Defoliation of in vitro shootlets of Azadirachta excelsa (Jack) M. Jacobs - A possible solution. The Malaysian Forester, 71(1):33-37.

Atta-Alla H.K., Moghazy E.I., Waly A.K. and Mohammed S. (2003). Micropropagation of Bombax malabaricum and Callistemon lanceolatus. Alex. J. Agric. Res., 48(1):103114.

Banilas G. and Korkas E. (2007). Rapid microprapagation of grapevine cv. Agiorgitiko through lateral bud development. J. Sci. \& Tech., 2(3):31-38.

Behera A. and Thirunavoukkarasu M. (2006). In vitro micropropagation of Desmodium gangeticum (L.) DC. through nodal explants. Indian J. of Plant Physiology. 11(1):83-88.

Bhattacharya S. and Bhattacharya S. (2010). In Vitro Propagation of Jasminum officinale L.: A Woody Ornamental Vine Yielding Aromatic Oil from Flowers. Methods in Molecular Biology, 589:117-126. (Cited in Protocols for In vitro Propagation of Ornamental Plants, chapter 12, by Jiain S.M. and Ochatt S.J., Humana Press, 2010).

Burasheed R. K., El-Wakeel H. M. and Desouky I. M. (2006). Some factors affecting in vitro propagation of Barhee and Khalas date palm cultivars. Anal. Agric. Sci. (Cairo). 51(1):191-201.

Cao J. and Earle E.D. (2003). Transgene expression in broccoli (Brassica oleracea var. italica) clones propagated in vitro via leaf explants. Plant Cell Reports. 21(8):789796.

Dubois M., Gilles K.A., Hamilton J.K., Rebers P.A. and Smith F. (1956). Colorimetric method for determination of sugars and related substances. Anal. Chem., 28: 350356.

Duncan's Multiple Range Test (1955). Multiple range and Multiple $\mathrm{F}$ test. J. Bionetrics, $11: 1-42$.

Ebrahim M. K. H. and Ibrahim I. A. (2000). In vitro growth and development of Maranta leuconeura (cv. Kerchoviana) as affected by medium gelation and $\mathrm{pH}$ value. Egyptian $\mathrm{J}$. Hort., 27(1):55-67.

Hashem M. E., Gomaa S. A., Saadawy F. M. and Abdul-Moneem E. Nermeen (2005). Propagation of some hard to root ornamental plants by tissue culture, III-Rooting stage. Fayoum J. Agric. Res. \& Dev., 19(1):108118.

Hongrat R., Tantiwiwat S. and Nakorn M. N. (2005). In vitro propagation of Cryptocoryne cordata. Proceedings of $43^{\text {rd }}$ Kasetsart Univ. Annual Conference, Thailand, 1-4 February, 2005. Subject: Plants. Kasetsart Univ., Bangkok, Thailand, 483-490.

Hung C.D., Johnson K. and Torpy F. (2006). Liquid culture for efficient micropropagation of Wasabia japonica (Miq.) Matsumura. In Vitro Cellular \& Developmental Biology Plant. 42(6):548-552.

Iapichino G. and Airo' M. (2002). Micropropagation of Polygala myrtifolia. Esperienze sulla propagazione in vitro di Polygala. Italus Hortus. 9(3):54-56.

Iapichino G. (2004). Improved micropropagation in Polygala myrtifolia. In Vitro Cellular \& Developmental Biology - Plant. 40(1):8689.

Iqbal M. J., Khan M. M., Fatima B., Asif M. and Abbas M. (2003). In vitro propagation of "Hybrid Tea" roses. Pakistan J. Agric. Sci. 40(3/4):155-163.

Mehta R., Sharma S. and Nath A. K. (2007). In vitro selection and biochemical characterization of carnation (Dianthus caryophyllus L.) callus culture tolerant to Alternaria dianthi. Indian Journal of Plant Physiology. 12(2):120-126.

Moran, R. (1982). Formulae for determination of chlorophyllous pigments extracted with N-N dimethyl-formamide. Plant Physiol., 69:1376-1381.

MSTAT Computer Program (1985). Software Program for Design, Management and Analysis Experimental (version 4.0), Michigan State Univ.

Murashige T. and Skoog F. (1962). A revised medium for rapid growth and bioassays with tobacco tissue cultures. Physiol. Plant. 15(3): 473-497.

Nisha M.C., Rajeshkumar S., Selvaraj T. and Subramanian. M.S. (2009). A valued Indian medicinal plant - Begonia malabarica Lam: Successful plant regeneration through various explants and field performance. Maejo Int. J. Sci. Tech. 3(2):261-268. 
Oakman H. (1995). Harry Oakman's What Flowers When: The Complete Guide to Flowering Times in Tropical and Subtropical Gardens. University of Queensland Press (Australia). p 73.

Orlikowska T., Sabala I., and Kucharska D. (2000). Rooting of axillary shoots of Codiaeum variegatum Blume cv. Excellent obtained in vitro from defoliated shoot explants. Acta Horticulturae., 530:253-256.

Radice S. (2000). Micropropagation of Codiaeum variegatum (L) Blume cv Norma. Phyton-International Journal of Experimental Botany. 69:143-146.

Romano A., Barros S. and Martins-Loucao M. A. (2002) Micropropagation of the Mediterranean tree Ceratonia siliqua. Plant Cell, Tissue and Organ Culture. 68(1):35-41.
Romano A. and Martins-Loucao M. A. (2003). Strategies to improve rooting and acclimatization of cork oak. Acta Horticulturae. 616:275-277.

Snedecor G. W. and Cochran W. G. (1980). Statistical Methods, $6^{\text {th }}$ ed., Iowa State Univ. Press, Iowa, USA.

Waseem K., Jilani M.S. and Khan M.S. (2009). Rapid plant regeneration of chrysanthemum (Chrysanthemum morifolium L.) through shoot tip culture. Afr. J. Biotechnol. 8(9):1871-1877.

Zeng L., Xu H., Zeng Y., Luan A. and Wang H. (2009). High efficiency in vitro plant regeneration from epicotyl explants of Ponkan Mandarin (Citrus reticulata Blanco). In Vitro Cellular \& Developmental Biology Plant, 45(5): 559-564.

$$
\begin{aligned}
& \text { تأثير بعض طرق التدعيم وتركيزات إندول حمض البيوتريك والتفاعل بينهما }
\end{aligned}
$$

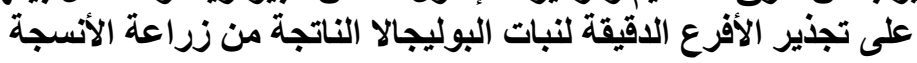

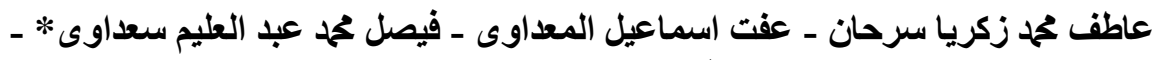

$$
\begin{aligned}
& \text { * طارق عحم نور الاين } \\
& \text { قسم بساتين الزينة_ كلية الزر اعة - جامعة القاهرة ـ الجيزة ـ مصر }
\end{aligned}
$$

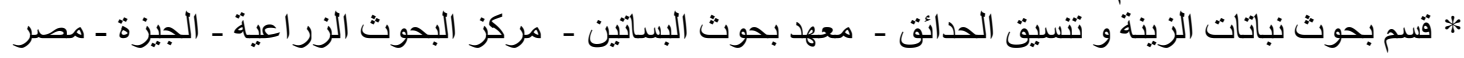

\section{ملخص معبدان}

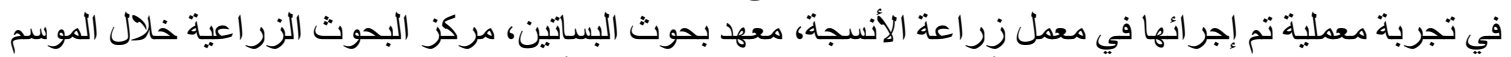

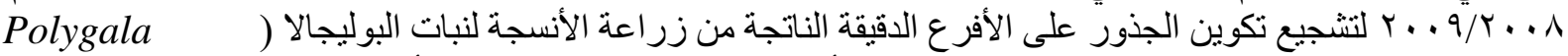

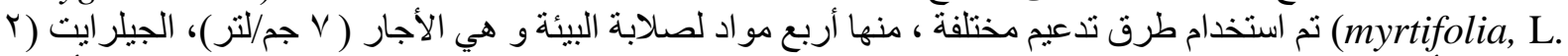

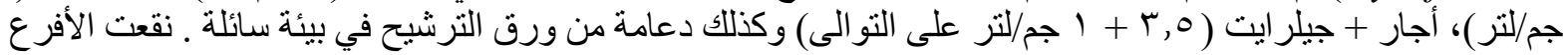

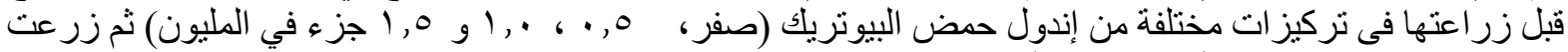

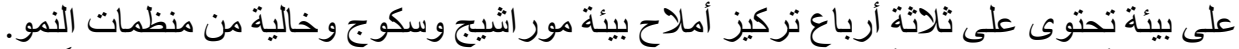

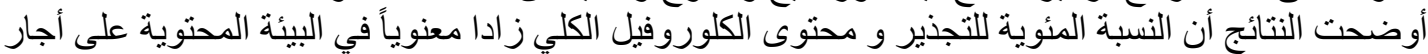

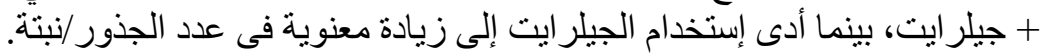

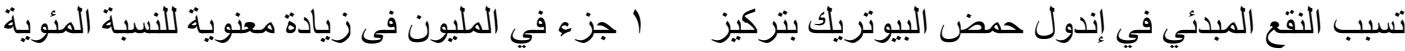
للتجذير ، و عدد الجذور/نبتة، وطول الجذر، ومحتوى الكلوروفيل الكلى ومحتوى الإندولات الكلية ومحتوى السكريات الذائبة الكلية.

وفيما يتعلق بالتفاعل بين طريقة التدعيم وتركيز ات إندول حمض البيوتريك ، وجد أن إستعمال الأجار + جيلر ايت

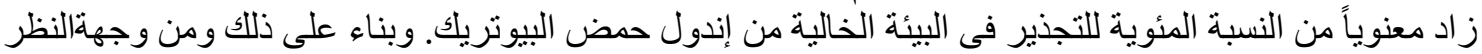

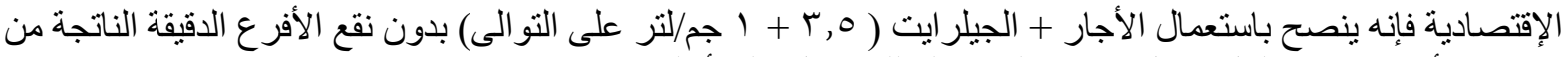

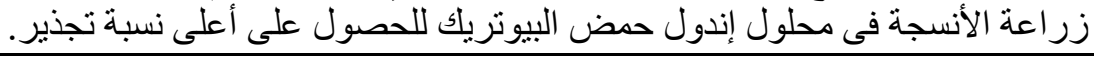

